\title{
A ROYAL PRIESTHOOD: LITERARY AND INTERTEXTUAL PERSPECTIVES ON AN IMAGE OF ISRAEL IN EXODUS 19:6'
}

\section{John Arthur Davies}

This thesis explores the background, literary setting, meaning and significance within its wider canonical context of the image of God's people as a 'kingdom of priests' in the divine declaration of Exodus 19:6. Most recent interpreters have argued for (or assumed) either a passive understanding of the word translated 'kingdom' (Israel is God's realm) or an active-elite understanding (Israel is a nation with a ruling priestly caste). Adopting a final form or literary approach to the text, this thesis argues on syntactic and contextual grounds for a view no longer fashionable-the active-corporate interpretation. On this view, God's commitment to Israel is seen as a declaration of the privileged position of the elect nation. God's people are his treasure-that is, in distinction to other nations, they enjoy the status of royalty and priesthood, depicted in terms of access to his heavenly court. This active-corporate interpretation is one which underlies many ancient renderings and interpretations of the passage (including those in the New Testament).

The words of the declaration speak of relationship rather than function. They indicate primarily the people's standing before God, rather than their obligation towards the other nations as is often supposed (intercession, service, mission), though it is not denied that there may be implications for human relationships of what it means to be the chosen people of God.

This royal-priestly designation of Israel draws on a rich world of ideology and symbolism, much of it common to the ancient Near East, where access to the divine realm is the prerogative of kings or their priests who acted as their surrogates. This rich symbolism has generally been all but overlooked, and occasionally explicitly denied,

1 John A. Davies, A Royal Priesthood: Literary and Intertextual Perspectives on an Image of Israel in Exodus 19:6 (unpublished Ph.D. thesis, University of Sydney, 2000); supervisor: Dr Ian Young. 
when it comes to elucidating the meaning of Exodus 19:6. It is the discerning of this symbolism in the context of this passage, and in some of its intertextual links, which constitutes one of the central contributions of this thesis. Thus, for example, the eagle imagery of Exodus 19:4 is to be seen against the background of Egyptian and Mesopotamian royal iconography.

The divine declaration comes at the pivotal point of the book of Exodus. Israel is in transition from being slaves to one king (Pharaoh), to being honoured royal guests in the court of another (God). This notion of the anticipated then declared status of Israel as a royal company of priests is seen to undergird much of the rest of the book of Exodus. The burning bush episode in chapter 3 is seen to be a precursor to the experience of the whole people at Sinai, and a pointer to the royal-priestly character of their encounter with God. The theophany, or manifestation of God on the mountain in chapter 19 serves a number of functions. It demonstrates the awesome nature of God, it enhances the prestige of the people who witness the event (as it did for any king who received such a revelation) and it heightens the dramatic tension as the people, through fear, keep their distance and plead for mediation. A climactic point in the narrative is reached in Exodus 24:1-11, which depicts what is essentially a priestly ordination rite, at which point the people are symbolically prepared for an intimate encounter with God. The people's representatives then ascend God's mountain abode and are granted a vision of God in his heavenly temple. The expected ancient Near Eastern ideology is reversed as God feeds his new heavenly attendants rather than being fed by them.

Provision is made for the perpetuation of the experience and a regular graphic portrayal in an elaborate drama of the honorific estimation this people enjoys in relation to their God. The close structural links between the cultic material of Exodus and the Sinai encounter are noted. The tabernacle cult is seen to reflect the original good created order, an ideal world in which God resides, free from the corruption, disorder and death which characterise the world outside the sanctuary, as was the case with the paradise garden depicted in Genesis 2. Into this symbolically recreated world God invites his priests, men chosen by his appointment and consecrated by rites of passage for access to the divine realm. Priests, by their splendid attire, are a visual representation of regal dignity.

The Levitical priesthood as portrayed in Exodus is seen not as diminishing or supplanting the collective royal priesthood, but as 
providing a visual model of that vocation, and secondly as facilitating it. Priests, like angels, their heavenly counterparts, demonstrate what it means to gain access to the presence of God, to worship and serve him in an environment where the restrictions to access have been removed. They and the world they frequent are pointers to the potential for the repristination of the cosmos.

The Sinai pericope, long regarded as a literary patchwork, is seen to have a coherence, and a rationale for the interweaving of narrative, law and cultic material is suggested which is consistent with the declaration of Israel as a 'royal priesthood'.

Coming at the beginning of the Sinai pericope, and in particular as the prelude to the theophany and giving of the law, the declaration of Exodus 19:4-6 has a significant bearing on our understanding of the character of the Sinai covenant. This covenant, with its attention to the stipulations, is frequently placed in contrast to the 'promise' covenant with Abraham. It is argued in this thesis that the discontinuities with the Abrahamic covenant are not to be exaggerated. The stipulations are part of the grace, indicating more fully to Israel what it will mean to live as God's royal priesthood in his sanctuary land. The suzerainty-vassal treaty, which has been pressed into service as the analogy for understanding the Sinai covenant is not without its usefulness, but there are other ancient analogies which might with equal validity be explored. In particular, the treaty of grant of royal favour, especially the grant of the privilege of priesthood, known from Mesopotamian texts, is suggested as an instructive analogy for the Sinai covenant.

Finally, while the phrase 'kingdom of priests' is unique in the Hebrew Bible to Exodus 19:6, the concept of Israel's collective royalty and priesthood is not. A number of passages with intertextual links to the Exodus locus are considered, and these are seen to be compatible with or to lend support to the interpretation developed in the thesis. Passages considered include Numbers 16, Hosea 4:4-9, Micah 4:8, Psalm 114:2, Isaiah 61:6-10, and Zechariah 3. 